\title{
Ichthyotoxicity studies of milkfish Chanos chanos fingerlings exposed to a harmful dinoflagellate Alexandrium minutum
}

\author{
Chih-Yu Chen ${ }^{\mathrm{a}, *}$, Hong-Nong Chou ${ }^{\mathrm{b}}$ \\ ${ }^{a}$ Science and Technology Information Center, National Science Council, 15F, No. 106, Hoping E. RD., Sec. 2, \\ Taipei 106-36, Taiwan, ROC \\ ${ }^{\mathrm{b}}$ Institute of Fisheries Science, National Taiwan University, Taipei, Taiwan, ROC
}

Received 16 February 2001; received in revised form 8 April 2001; accepted 8 May 2001

\begin{abstract}
Milkfish (Chanos chanos Forsskal) fingerlings were treated with toxic, nontoxic dinoflagellate Alexandrium minutum cells or toxic algal extract in the water medium without any aeration. Mortality of fish increased with increasing concentrations of toxic, nontoxic algal cells and water-soluble toxic algae extract. Milkfish fingerlings, which were exposed to toxic algae $\left(1.5 \times 10^{4}-3.0 \times 10^{4}\right.$ cells $\left./ \mathrm{ml}\right)$ or algal extract $\left[5.13 \times 10^{3}-2.05 \times 10^{4}\right.$ cells $/ \mathrm{ml}, 0.195 \mathrm{MU} / 10^{4}$ cells (toxin concentration)] for $24 \mathrm{~h}$, revealed by light microscopic observations a noticeable edema, hyperplasia and necrosis of secondary gill lamellae. The same toxicological symptom was observed in fish exposed to pure saxitoxin (STX) $\left(6.475 \times 10^{-2} \mu \mathrm{g} / \mathrm{ml}\right)$ in the water medium. A higher critical oxygen pressure and oxygen consumption rate were also found in the milkfish fingerlings exposed to toxic algae extract $\left(5.13 \times 10^{3}-2.05 \times 10^{4}\right.$ cells $\left./ \mathrm{ml}\right)$ and STX $(6.475 \times$ $10^{-2} \mu \mathrm{g} / \mathrm{ml}$ ). The cells of nontoxic A. minutum did not cause the gill damage to milkfish, and the extract of nontoxic algae did not cause an increase in oxygen consumption rate or critical oxygen demand of milkfish. From these results, we infer that toxic cells and its extract cause nonspecific response in gill tissues of milkfish. An instant increase in oxygen consumption rate and oxygen demand may be one of the major causes of fish death. (C) 2001 Elsevier Science B.V. All rights reserved.
\end{abstract}

Keywords: Milkfish; Alexandrium minutum; STX; Toxicological symptom; Oxygen demand

\footnotetext{
" Corresponding author. Tel.: +886-2-27377850; fax: +886-2-27377669.

E-mail address: cychen@mail.stic.gov.tw (C.-Y. Chen).
} 


\section{Introduction}

Alexandrium minutum is a toxic dinoflagellate that causes paralytic shellfish poisoning (PSP) in Taiwan. It is distributed in the coastal waters of southern Taiwan and often occurs in fish ponds of Pingtung county (Su et al., 1996; Hwang and Lu, 2000). Blooms of A. minutum have occurred in many aquaculture ponds and caused PSP toxin accumulation in purple clam ( Hiatula rostrata) resulting in two food poisoning incidents in 1986 and 1991 (Chou and Su, 1989; Hwang et al., 1992). Moreover, toxic A. minutum blooms have caused mass mortalities of cultured organisms, such as grass prawn (Penaeus monodon) in 1989 (Su et al., 1993) and milkfish (Chanos chanos) in 1992, 1995-1998 (Chen, 1998).

PSP toxins are among the most common and deadly phycotoxins in the marine environment. They are mainly produced by the dinoflagellates Alexandrium, Pyrodinium, and Gymnodinium (Hallegraeff, 1995), and some species of blue-green algae (Negri and Jones, 1995; Carmichael et al., 1997). The toxins are known to affect shellfish, crustaceans and finfish (Ives, 1987; Shumway and Cucci, 1987; Haya et al., 1990). Blooms of the PSP toxin-containing dinoflagellates have been implicated in some finfish kills in nature (White et al., 1989; Koizumi et al., 1996). Laboratory experiments have shown that PSP toxins are lethal to various marine fishes, including larval (Gosselin et al., 1989; Robineau et al., 1991a,b) and adult fish (White, 1981; Saito et al., 1985; Gubbins et al., 2000). As for milkfish, when a bloom occurred, fishes appeared to stay on the surface, often with their heads out of the water. The symptoms of dying milkfish appeared to be due to environmental hypoxia, however, the action mode of PSP toxin is not yet clear.

The main purpose of this study was to explore the action mode of PSP toxins on milkfish. We report on the response in the laboratory of milkfish fingerlings to exposure to toxic or nontoxic A. minutum Halim, water-soluble cell extract and pure saxitoxin (STX). Furthermore, we have investigated how toxic algae, algal extract and STX affect the gill histology, oxygen consumption rate and critical oxygen pressure.

\section{Materials and methods}

\subsection{Experimental organisms}

To discriminate the effect of the PSP toxins from other experimental causes, milkfish fingerlings were exposed to either a toxic or nontoxic strain of the species A. minutum. Toxic strain of A. minutum Amtk-1 was isolated in 1986 from Tungkang area where PSP occurred due to the ingestion of purple clams. Nontoxic strain Amtk-6 was isolated in 1994 from a Tungkang milkfish culture pond. Unialgal cultures were kept in K-medium, illuminated with continuous light of $3000 \mathrm{~lx}$ at $20-22{ }^{\circ} \mathrm{C}$. Milkfish $(C$. chanos), total size range $12-15 \mathrm{~cm}$, wet weight range $10-25 \mathrm{~g}$, were collected from aquaculture pond at Tungkang, Pingtung Prefecture. The fish were transferred into tanks with continuous seawater supply, and allowed to acclimate for 1 week before use. 


\subsection{Toxicological symptom and $L C_{50}$}

The 24-h ichthyotoxicity tests on milkfish were conducted in 30-1 fish tank, without aeration; the temperature, salinity and $\mathrm{pH}$ value were kept at $23{ }^{\circ} \mathrm{C}, 10 \mathrm{ppt}$ and 7.7-7.9, respectively. All experiments were carried out in duplicate with 10 fingerlings used in each replicate. Ten fingerlings were kept in tanks with aeration and without aeration as control groups. Algal cells of both toxic and nontoxic species were harvested in exponential growth phase. To evaluate the effects of toxic algae (Amtk-1), nontoxic algae (Amtk-6) and toxic algal extract on milkfish, the cell concentrations were 0, $1.5 \times 10^{4}, 2.0 \times 10^{4}, 2.5 \times 10^{4}$ and $3.0 \times 10^{4}$ cells $/ \mathrm{ml}$. Because Amtk-1 could produce PSP toxins, the water-soluble algal extract was prepared by crude PSP toxin extraction method (Chen, 1998). The toxicity of PSP toxin was determined by HPLC from our previous studies (Chen and Chou, 2001). Algae samples were counted and then trapped in fiberglass; the retained algal cells were extracted with $95 \%$ acetic alcohol $(\mathrm{pH}=2)$. The extracts were concentrated and transferred to vials by means of $0.03 \mathrm{~N}$ acetic acid, defatted with chloroform; the supernatant toxic algal extract was subjected to HPLC analysis and divided into $5.13 \times 10^{3}, 1.03 \times 10^{4}, 1.54 \times 10^{4}$ and $2.05 \times 10^{4}$ cells $/ \mathrm{ml}\left[0.195 \mathrm{MU} / 10^{4}\right.$ cells (toxin concentration)]. The dose response of test organisms obtained from the replicates of each treatment were analyzed using by the method of probit analysis (Finney, 1971). The $\mathrm{LC}_{50}$ values and $95 \%$ confidence limits were calculated using a microcomputer program (Trevors and Lusty, 1985).

\subsection{Gill histopathology}

All treated fish were dissected for histological examination of the gills. Gills were fixed in Davidson's fixative (Humason, 1979), dehydrated in a series of alcohol concentrations, cleared in xylene, embedded in paraffin, sectioned at $5 \mu \mathrm{m}$ thickness, and stained with Harris' hematoxylin (Luna, 1977).

\subsection{Oxygen consumption rate and critical oxygen pressure}

The procedures of measurements in oxygen consumption rate were simplified from Schreck and Moyle (1990). Measurements were made using a dissolved oxygen probe (WTW, OX196). One specimen of milkfish was in a 2-1 sealed oxygen saturated flask (there were four replicates used for each treatment). The temperature, salinity and $\mathrm{pH}$ value were kept at $25{ }^{\circ} \mathrm{C}, 10 \mathrm{ppt}$ and 6.8 , respectively. The rate of oxygen consumption was calculated from the difference between the two dissolved oxygen (D.O.) values (initial to fish death), and expressed as milligram oxygen per gram body weight per hour $(\mathrm{mg} / \mathrm{g} / \mathrm{h})$. The concentration of algal extract used were equivalent to 0 (control), $5.13 \times 10^{3}, 1.03 \times 10^{4}, 1.54 \times 10^{4}$ and $2.05 \times 10^{4}$ cells $/ \mathrm{ml}$. We also tested how nontoxic algal extract and pure saxitoxin (STX) $\left(6.475 \times 10^{-2} \mu \mathrm{g} / \mathrm{ml}\right)$ affected the rate of oxygen consumption in milkfish. Furthermore, we recorded the critical oxygen pressure, or the lowest dissolved oxygen value necessary for the aquatic organism to 
Table 1

The $24-\mathrm{h} \mathrm{LC}_{50}$ values and their $95 \%$ confidence limits of milkfish fingerlings $(n=10)$

The toxicity tests on milkfish were conducted with toxic, nontoxic strain and toxic strain extract of $A$. minutum.

\begin{tabular}{ll}
\hline & $\mathrm{LC}_{50}($ cells $/ \mathrm{ml})$ \\
\hline Toxic strain & $19,819(17,388,22,590)$ \\
Nontoxic strain & $21,060(18,774,23,625)$ \\
Toxic strain extract & $10,256(8205,13,300)$ \\
\hline
\end{tabular}

survive. We compared the oxygen consumption rate and critical oxygen pressure between control and experimental groups with each test (ANOVA and $t$-test).

\section{Results}

The 24-h $\mathrm{LC}_{50}$ values and their 95\% confidence limits are shown in Table 1. The $\mathrm{LC}_{50}$ value of toxic A. munutum treatment was lower than that of the nontoxic $A$.

$\mathbf{A}$
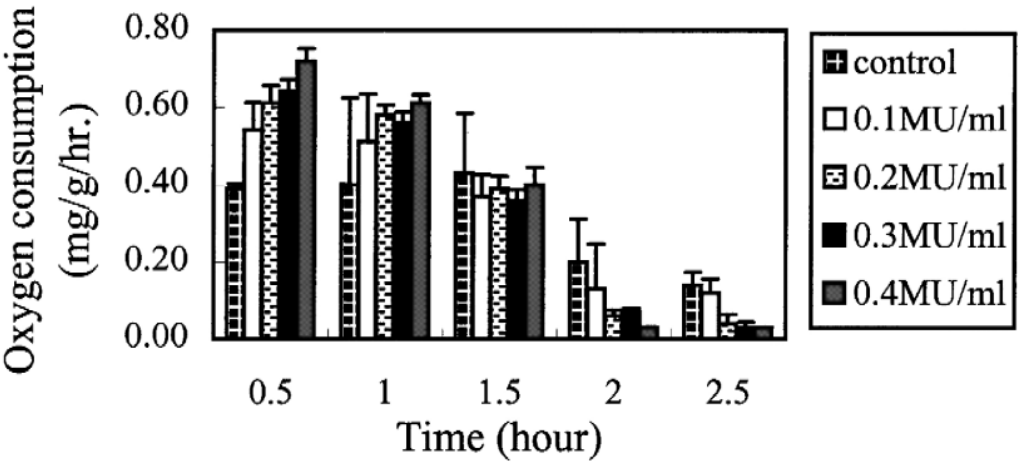

B
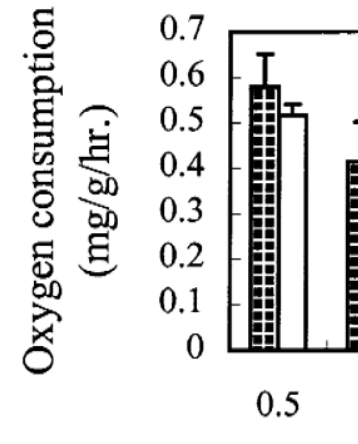
munutum treatment. Mortality significantly increased with increased cell densities, and concentrations of toxic algal extract $\left(r^{2}=0.87, P<0.05\right)$. In control tanks without aeration, there were no mortalities during the 24-h experiment. As for the toxicological symptom, milkfish in each treatment presented symptoms of hypoxia. The fish swam erratically, remained close to the water surface, and finally died with an open mouth. These symptoms were similar to those recorded in field observations of bloomed culture pond. When fish were provided continuous aeration, there were no mortalities in either control or experiment groups within $24 \mathrm{~h}$.

Light microscope examination revealed histopathological changes in the gills of milkfish after exposure to toxic A. minutum and toxic algal extract. Milkfish fingerlings, which were exposed to toxic algae or their extract, exhibited a noticeable edema, hyperplasia and necrosis of secondary lamellae of the gills. The same toxicological symptom was also observed in fish treated with pure STX $\left(6.475 \times 10^{-2} \mu \mathrm{g} / \mathrm{ml}\right)$, while the gills of fish exposed to nontoxic A. minutum were similar to those of the control. In this experiment, we found that the degree of gill damage was not proportional to the concentration of toxic algae or their extract. We also measured the $\mathrm{pH}$ value and D.O. value of control and experiment groups, and found the values were similar between control group and every treatment group.

Fig. 1A shows the rate of oxygen consumption of milkfish fingerlings exposed to different concentrations of toxic A. minutum algal extract. In the early stage $(0-0.5 \mathrm{~h})$, the rate of oxygen consumption of algal extract treatment groups were higher than the control group. Furthermore, the higher the concentrations of algal extract, the higher the rate of oxygen consumption (ANOVA, $P<0.05)$. In the late stage $(2.0-2.5 \mathrm{~h}$ ), the rate of oxygen consumption of algal extract treatment groups were lower than the control

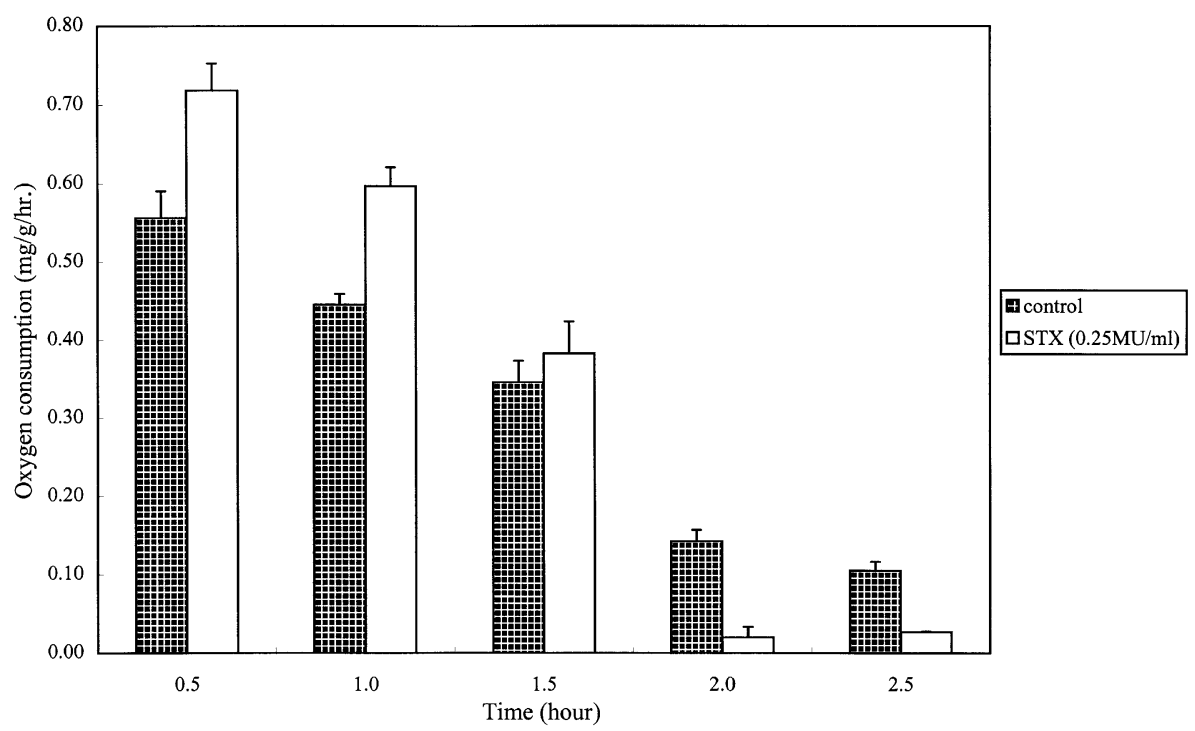

Fig. 2. The rate of oxygen consumption of milkfish finglings exposed to pure STX toxin. Values are mean \pm SE. $(P<0.05)$. 
Table 2

The critical oxygen pressure of milkfish fingerlings

The treatment was conducted with toxic, nontoxic strain extract of A. minutum, and pure STX toxins. Values are mean \pm SE.

Toxicity: $0.195 \mathrm{MU} / 10^{4}$ cells; $1 \mathrm{MU}=0.259 \mu \mathrm{g}$ STX.

\begin{tabular}{lcl}
\hline & $\begin{array}{l}\text { Body weight }(\mathrm{g}) \\
(n=4)\end{array}$ & $\begin{array}{l}\text { Critical oxygen pressure } \\
(\mathrm{mg} / \mathrm{l})\end{array}$ \\
\hline Toxic algae extract & $18.2 \pm 1.09$ & $0.10 \pm 0.00$ \\
Control & $17.2 \pm 0.93$ & $0.35 \pm 0.06$ \\
$5.13 \times 10^{3}$ cells $/ \mathrm{ml}$ & $17.3 \pm 1.00$ & $0.35 \pm 0.06$ \\
$1.03 \times 10^{4} \mathrm{cells} / \mathrm{ml}$ & $17.6 \pm 0.74$ & $0.38 \pm 0.05$ \\
$1.54 \times 10^{4} \mathrm{cells} / \mathrm{ml}$ & $16.1 \pm 0.62$ & $0.48 \pm 0.05$ \\
$2.05 \times 10^{4}$ cells $/ \mathrm{ml}$ & & \\
Nontoxic algae extract & $17.4 \pm 0.86$ & $0.10 \pm 0.00$ \\
Control & $17.7 \pm 1.20$ & $0.10 \pm 0.00$ \\
$9.57 \times 10^{4}$ cells $/ \mathrm{ml}$ & & \\
STX & $17.8 \pm 0.55$ & $0.10 \pm 0.00$ \\
Control & $16.4 \pm 0.52$ & $0.50 \pm 0.00$ \\
$6.475 \times 10^{-2} \mu \mathrm{g} / \mathrm{ml}$ &
\end{tabular}

group. In the pure STX $\left(6.475 \times 10^{-2} \mu \mathrm{g} / \mathrm{ml}\right)$ treatment, the rate of oxygen consumption was significantly higher than the control group at $0-1.0 \mathrm{~h}(t$-test, $P<0.05)$, and lower than the control group at $2.0-2.5 \mathrm{~h}$ (Fig. 2). In the nontoxic A. minutum algal extract treatment, there was no significant difference between the control and treatment group ( $t$-test, $P>0.05$; Fig. 1B). Because toxic cell extract and STX caused gill damage, we suggested that in the early stage $(0-1.0 \mathrm{~h})$, milkfish fingerlings were hyperventilating so that oxygen consumption rates of experiment groups were higher than control group; in the late stage, lower oxygen consumption rates of treated fish might be due to the gills response to the toxin, resulting in reduced oxygen uptake. As for the demand of critical oxygen pressure, the values of both toxic algal extract and STX treatment were significant higher than that of the control group $(t$-test, $P<0.05)$. The critical oxygen pressure value of nontoxic algal extract treatment was the same as that of the control group (Table 2), which means that nontoxic algal extract would not affect the critical oxygen pressure value.

\section{Discussion}

From the results shown, it was suggested the critical lethal factors for milkfish in the blooming environment were as follows: (1) physical factor-the toxic or nontoxic algae block the gill, and asphyxiation is the cause of death; (2) physiological factor-the increase of oxygen consumption rate and critical oxygen pressure. However, the higher critical oxygen pressure caused by toxic cell extract makes milkfish raise their oxygen demand and the fish cannot tolerate oxygen-deficient environment. 
Concerning the published reports dealing with the toxic effects on finfish of the genus Alexandrium, White (1984) mentioned finfish were sensitive to PSP toxins; Mortensen (1985) reported Gonyaulax (=Alexandrium) excavata caused acute histopathological damage to the gills. White et al. (1989) and Gosselin et al. (1989) described the mortality of fish larva was correlated with A. tamarensis concentrations. Our results also have the similar toxicological and histopathological symptoms as that of the above studies. Koizumi et al. (1996) suggested that mass mortalities of marine organisms were due to bloom-related anoxia and hypoxia of $G$. polygramma. These results of our study are the first evidence of how the cell extract from A. minutum affect the oxygen consumption rate and critical oxygen pressure of fish.

In Taiwan, massive mortality of milkfish and other fish species occurred recently in the area of Kaohsiung and Pingtung when A. minutum bloomed in the culture ponds (Chen, 1998). Cell concentrations of $A$. minutum reached a level of $2.42 \times 10^{4}$ cells $/ \mathrm{ml}$, the same cell concentration of a well-established laboratory culture. It was found that toxin concentrations of the blooming species was within the range of $2.43 \times 10^{-4}-3.88 \times 10^{-5} \mathrm{MU} /$ cell, similar to those of cultured strains. These results suggest that the $\mathrm{LC}_{50}$ value (approximately $2.00 \times 10^{4}$ cells $/ \mathrm{ml}$ ) of that we reported for milkfish fingerling in the laboratory is also relevant in the field.

Many studies have found gill structural changes are induced by toxicants (Scott and Rogers, 1980; Solangi and Overstreet, 1982; Nowak and Barbara, 1992; Tamse et al., 1995). From our results, the damage to the gills strongly suggest this is a common mode of action by which hyperventilation is induced because most of these histological changes increase the diffusion distance for oxygen from the water to the blood, which again could explain the separation of the respiratory epithelium. Our results uphold the concept (Mallatt, 1985) that toxicant-induced alteration in gill histology are largely nonspecific, because similar types of lesions occur under a wide range of toxicant-exposure conditions.

Acute exposure to some chemicals can cause rapid destruction of the gill lamellae within a few hours, and further affect the rate of oxygen consumption (Heath, 1995). The hypoxia is undoubtedly a major contributing factor to mortality from acute exposure to toxic algae and algal extract. Asian catfish Clarias macrocephalus will increase air-breathing frequency in the presence of waterborne toxins (Kulakkattolickal and Kramer, 1988). Several previous studies have demonstrated increased oxygen demand in the presence of organic toxicants (Davis, 1973; Dalela et al., 1980; Bakthavathsalam and Reddy, 1983). This may be a consequence of the increased activity associated with attempted avoidance of toxicants by the fish. Both organic toxicants and PSP toxins affect the oxygen consumption rate of fish. That is, the impact of PSP toxins on milkfish is a nonspecific response. Nevertheless, our finding of a positive correlation between oxygen and toxicity in milkfish suggests, that hypoxia increases toxicity by increasing exposure of the gill epithelium to PSP toxins, in fish capable only of aquatic respiration.

STX and PSP toxin-containing toxic algal cell extracts cause similar effect on milkfish, including the change of oxygen consumption rate and critical oxygen pressure. Such results indicate that PSP toxins seem to be involved in decrease of gas exchange in the gills. In mammals, PSP toxins will block nerve cells, thus preventing conductance of signals along the neuron (Baden and Trainer, 1993). We suggest that PSP toxins might 
be functioning on the gill epithelium, induce gill damage, and then impact oxygen uptake.

\section{Acknowledgements}

This work was supported by grants from National Science Council (Grant no. NSC-88-2312-B-002-039) awarded to H.N. Chou, Taiwan, Republic of China. [SS]

\section{References}

Baden, D.G., Trainer, V.L., 1993. Mode of action of toxins of seafood poisoning. In: Falconer, I.R. (Ed.), Algal Toxins in Seafood and Drinking Water. Academic Press, London, pp. 49-74.

Bakthavathsalam, R., Reddy, Y.S., 1983. Changes in bimodal oxygen uptake of an obligate air breather Anabas testudineus (Bloch) exposed to lindane. Water Res. 17, 1221-1226.

Carmichael, W.W., Evans, W.R., Yin, Q.Q., Bell, P., Moczydlowski, E., 1997. Evidence for paralytic shellfish poisons in the freshwater cyanobacterium Lyngbya wollei (Farlowex Gomont) comb. nov. Appl. Environ. Microbiol. 63, 3104-3110.

Chen, C.Y., 1998. Purple Clam Accumulation, Food Chain Transmission and Ichthyotoxicity Studies of Paralytic Shellfish Poisons from Alexandrium minutum Halim. PhD thesis, National Taiwan University.

Chen, C.Y., Chou, H.N., 2001. Accumulation and depuration of paralytic shellfish poisoning toxins by purple clam Hiatula rostrata Lighttoot. Toxicon 39, 1029-1034.

Chou, H.N., Su, H.M., 1989. Allelochemicals in marine ecosystems. In: Chou, C.H., Waller, G.R. (Eds.), Phytochemical Ecology: Allelochemicals, Mycotoxins and Insect Pheromones, Institute of Botany, Academia Sinica Monograph Series No. 9, Taipei, R.O.C., pp. 119-128.

Dalela, R.C., Bansal, S.K., Gupta, A.K., Verma, S.R., 1980. Short-term stress on the oxygen consumption of a freshwater teleost Saccobranchus fossilis, following lethal and sublethal levels of Chlordane, Metasystox and Sevin. Int. J. Environ. Stud. 15, 229-235.

Davis, J.C., 1973. Sublethal effects of bleached kraft pulp mill effluent on respiration and circulation in sockeye salmon (Oncorhynchus nerka). J. Fish Res. Board Can. 30, 369-377.

Finney, D.J., 1971. Probit Analysis. 3rd edn. Cambridge Univ. Press, London, p. 333.

Gosselin, S., Fortier, L., Gagne, J.A., 1989. Vulnerability of marine fish larvae to the toxic dinoflagellate Protogonyaulax tamarensis. Mar. Ecol. Prog. Ser. 57, 1-10.

Gubbins, M.J., Eddy, F.B., Gallacher, S., Stagg, R.M., 2000. Paralytic shellfish poisoning toxins induce xenobiotic metabolising enzymes in Atlantic salmon (Salmo salar). Mar. Environ. Res. 50, 479-483.

Hallegraeff, G.M., 1995. Harmful algal blooms: a global overview. In: Hallegraeff, G.M., Anderson, D.M., Cembella, A.D., Enevoldsen, H.O. (Eds.), Manual on Harmful Marine Microalgae. UNESCO, Paris, pp. $1-22$.

Haya, K., Martin, J.L., Waiwood, B.A., Burridge, L.E., Hungerford, J.M., Zitko, V., 1990. Identification of paralytic shellfish toxins in mackerel from southwest bat of Fundy, Canada. In: Graneli, E., Sundstrom, B., Edler, L., Anderson, A.D. (Eds.), Toxic Marine Phytoplankton. Elsevier, New York, pp. 350-355.

Heath, A.G., 1995. Water Pollution and Fish Physiology. 2nd edn. Lewis Publishers, Boca Raton.

Humason, G.L., 1979. In: Freeman, W.H. (Ed.), Animal Tissue Techniques. 4th edn., pp. 135-147, San Francisco.

Hwang, D.F., Lu, Y.H., 2000. Influence of environmental and nutritional factors on growth, toxicity, and toxin profile of dinoflagellate Alexandrium minutum. Toxicon 38, 1491-1503.

Hwang, D.F., Tsai, Y.H., Cheng, C.A., Jeng, S.S., 1992. Comparison of paralytic toxins in aquaculture of purple clam in Taiwan. Toxicon 30, 669-672.

Ives, J.D., 1987. Possible mechanisms underlying copepod grazing responses to levels of toxicity in red tide dinoflagellates. J. Exp. Mar. Biol. Ecol. 112, 121-145. 
Koizumi, Y., Kohno, J., Matsuyama, N., Uchida, T., Honjo, T., 1996. Environmental features and the mass mortality of fish and shellfish during the Gonyaulax polygramma red tide occurred in and around Uwajima Bay, Japan, in 1994. Nippon Suisan Gakkaishi 62, 217-224.

Kulakkattolickal, A.T., Kramer, D.L., 1988. The role of air breathing in the resistance of bimodally respiring fish to waterborne toxins. J. Fish Biol. 32, 119-127.

Luna, L.G., 1977. Manual of Histologic Staining Methods of the Armed Forces Institute of Pathology. 3rd edn. American Registry of Pathology, New York.

Mallatt, J., 1985. Fish gill structural changes induced by toxicants and other irritants: a statistical review. Can. J. Fish. Aquat. Sci. 42, 630-648.

Mortensen, A.M., 1985. Massive fish mortalities in the Faroe Islands caused by a Gonyaulax excavata red tide. In: Anderson, D.M., White, A.W., Baden, D.G. (Eds.), Toxic Dinoflagellates. Elsevier, New York, pp. $165-170$.

Negri, A.P., Jones, G.J., 1995. Bioaccumulation of paralytic shellfish poisoning toxins from the cyanobacterium Anabaena circinalis by the freshwater mussel Alathyria condola. Toxicon 33, 667-678.

Nowak, Barbara, 1992. Histological changes in gills induced by residues of endosulfan. Aquat. Toxicol. 23, $65-83$.

Robineau, B., Gagne, J.A., Fortier, L., Cembella, A.D., 1991a. Potential impact of a toxic dinoflagellate (Alexandrium excavatum) bloom on survival of fish and crustacean larvae. Mar. Biol. 108, 293-301.

Robineau, B., Fortier, L., Gagne, J.A., Cembella, A.D., 1991b. Comparison of the response of five larval fish species to the toxic dinoflagellate Alexandrium excavatum (Braarud) Balech. J. Exp. Mar. Biol. Ecol. 152, $225-242$.

Saito, T., Noguchi, T., Takeuchi, T., Kamimura, S., Hashimoto, K., 1985. Ichthyotoxicity of paralytic shellfish poison. Bull. Jpn. Soc. Sci. Fish. 51, 257-260.

Schreck, C.B., Moyle, P.B., 1990. Methods for Fish Biology. American Fisheries Society, Maryland, pp. $338-362$.

Scott, A.L., Rogers, W.A., 1980. Histological effects of prolonged sublethal hypoxia on channel catfish Ictalurus punctatus (Rafinesque). J. Fish Dis. 3, 305-316.

Shumway, S.E., Cucci, T.L., 1987. The effect of the toxic dinoflagellate Protogonyaulax tamarensis on the feeding and behaviour of bivalve molluscs. Aquat. Toxicol. 10, 9-27.

Solangi, M.A., Overstreet, R.M., 1982. Histopathological changes in two estuarine fishes, Menidia beryllina (Cope) and Trinectes maculatus (Bloch and Schneider), exposed to crude oil and its water-suluble fractions. J. Fish Dis. 5, 13-35.

Su, H.M., Liao, I.C., Chiang, Y.M., 1993. Mass mortality of Prawn caused by Alexandrium tamarense blooming in a culture pond in southern Taiwan. In: Smayda, T.J., Shimizu, Y. (Eds.), Toxic Phytoplankton Blooms in the Sea. Elsevier, New York, pp. 329-333.

Su, H.M., Su, M.S., Liao, I.C., 1996. Can algicides be used to kill the toxic dinoflagellate, Alexandrium minutum, in aquaculture ponds? Acta Oceanogr. Taiwan. 35, 257-265.

Tamse, C.T., Gacutan, R.G., Tamse, A.F., 1995. Changes induced in the gills of milkfish (Chanos chanos Forsskal) fingerlings after acute exposure to Nifurprinol (Furanace; P-7138). Bull. Environ. Contam. Toxicol. 54, 591-596.

Trevors, J.T., Lusty, C.W., 1985. A basic microcomputer program for calculating $\mathrm{LD}_{50}$ values. Water, Air, Soil Pollut. 24, 431-442.

White, A.W., 1981. Sensitivity of marine fishes to toxins from the red-tide dinoflagellate Gonyaulax excavata and implications for fish kills. Mar. Biol. 65, 255-260.

White, A.W., 1984. Paralytic shellfish toxins and finfish. In: Ragelis, E. (Ed.), Seafood Toxins. American Chemical Society, Washington, DC, pp. 171-180.

White, A., Fukuhara, W.O., Anraku, M., 1989. Mortality of fish larvae from eating toxic dinoflagellates or zooplankton containing dinoflagellate toxins. In: Tomotoshi, O., Anderson, D.M., Nemoto, T. (Eds.), Red Tides, Biology, Environmental Science, and Toxicology. Elsevier, New York, pp. 395-398. 